\title{
SPOT REKRUTMEN KARANG PADA TERUMBU BUATAN BIOREEFTEK DI PERAIRAN PESISIR DESA KEROBOKAN, BULELENG, BALI
}

\author{
Eghbert Elvan Ampou ${ }^{a^{*}}$, Camellia Kusuma Tito ${ }^{a}$, Iis Triyuliantya ${ }^{a}$ Nuryani Widagtia ${ }^{a}$, \\ I Putu Mangku Mariasab

\begin{abstract}
aBalai Riset dan Observasi Laut, BRSDMKP, Kementerian Kelautan dan Perikanan.Jl. Baru Perancak, Negara- Jembrana, Bali 82251, Indonesia

${ }^{\mathrm{b}}$ True SCUBA Dive Center, Singaraja, Buleleng, Bali, Indonesia
\end{abstract} \\ *Koresponden penulis: eghbert.ampou@kkp.go.id
}

\begin{abstract}
Abstrak
Perairan pesisir Desa Kerobokan memiliki wilayah terumbu karang yang penting karena terdapat spot rekrutmen sebagai wilayah terumbu buatan alami. Penelitian ini bertujuan untuk mengetahui nilai indeks keanekaragaman, keseragaman dan dominansi karang pada terumbu buatan alami "Bioreeftek" di salah satu spot perairan pesisir Desa Kerobokan, Kecamatan Sawan, Kabupaten Buleleng, Provinsi Bali.Metode penelitian yang diaplikasikan adalah observasi dengan sensus visual dengan kamera bawah air dan peralatan selam SCUBA pada enam unit terumbu buatan. Pengambilan data observasi dilakukan pada September 2020. Total rekrutmen karang yang ditemukan sebanyak sembilan jenis biota pada terumbu buatan B1-B6 (B=Bioreeftek), yaitu Podobacia sp, Sponge, Atriolum robustum, Favites sp, Gorgonia sp, Porites sp, Diploastrea sp, Coralline algae dan Pocillopora damicornis. Indeks Keanekaragaman tertinggi B3 = 3,4; Indeks Keseragaman tertinggi B3 = 2, 48; Indeks Dominansi tertinggi B5 = 0,68. Biota yang paling banyak ditemukan pada terumbu buatan B1-B6 adalah Coralline algae dan karang Scleractinia dari jenis Favites sp. Kondisi kualitas air di perairan Buleleng menunjukan kondisi normaldan masih berada pada standar baku yang ditetapkan oleh Keputusan Menteri Lingkungan Hidup No. 51 Tahun 2004, kecuali konsentrasi nutrien.
\end{abstract}

Kata Kunci: Rekrutmen karang, Bioreeftek, kualitas air, sensus visual, Desa Kerobokan, Bali

\begin{abstract}
This study aims to determine the diversity index value, uniformity, and dominance of corals on natural artificial reefs "Bioreeftek" in Kerobokan Village coastal waters, Sawan District, Buleleng Regency, Bali Province. Data collection was carried out on September 2020. Observations with visual census using underwater cameras and SCUBA diving equipment was applied to observe coral recruitment in six artificial reef units. The results showed that there were nine types of biotas found on artificial reefs B1-B6 (B = bioreeftek), that were Podobacia sp, Sponge, Atriollum robustum, Favites sp, Gorgonia sp, Porites sp, Diploastrea sp, Coralline algae and Pocillopora damicornis. The highest diversity index found in $\mathrm{B} 3=3,4$; The highest uniformity index found $\mathrm{B} 3=2,48$; and the highest dominance index was in B5 $=0,68$. Coralline algae and Scleractinian corals (Favites $s p$ ) were abundantly found in artificial reefs B1B6. Water quality condition in Buleleng water generally showed a normal condition for supporting marine lifes, with exception of nutrient.
\end{abstract}

Keywords: Coral recruitment, Bioreeftek, water quality, visual census, Kerobokan Village, Bali

\section{PENDAHULUAN}

Indonesia termasuk salah satu negara anggota Coral Triangle Initiative (CTI) dan mempunyai jenis karang dengan keanekaragaman hayati yang tinggi [1]. Status terumbu karang di Indonesia saat ini menunjukkan relatif stabil khususnya terumbu karang yang masuk dalam kategori baik dan sangat baik, namun sebaliknya kategori terumbu karang jelek dan cukup mengalami fluktuasi yang signifikan[2], dampak dari perubahan iklim ditengarai memberikan kontribusi terjadinya proses fluktuasi tersebut[3]. Bali memiliki tingkat keragaman terumbu karang pembentuk spesies (hermatypic) dengan total 406 jenis dan daerah 
yang memiliki tingkat asosiasi ikan karang yang tinggi yang perlu dikelola secara berkelanjutan [4]-[6]dimana secara global juga sebagai pemasok keanekaragaman hayati kelautan tropis[7], [8].Kegiatan konservasi sangat perlu dilakukan agar ekosistem terumbu karang dapat berkelanjutan [9]dan salah satu bentuk program dalam mengurangi proses degradasi khususnya terumbu karang adalah dengan membuat terumbu buatan[10]-[12]. Terumbu buatan alami "Bioreeftek" sebagai salah satu media atau ruang yang disediakan sebagai tempat penempelan bagi larva karang dari tempurung kelapa sehingga data diartikan dapat dijadikan sebagai tempat atau spot rekruitmen. Rekrutmen karang adalah penempelan larva dan pertumbuhan ukuran yang dapat dilihat oleh mata telanjang sebagai proses penting dari dinamika populasi yang mendasari keberlanjutan eksistensi terumbu karang [13]. Kegiatan sensus visual melalui observasi untuk pendataan rekruiitmen karang dapat memberikan informasi mengenai jenis karang yang dapat tumbuh secara alami beserta distribusi dan kelimpahan karang yang ada [14]. Penempatan terumbu buatan alami "Bioreeftek" di perairan ekosistem pesisir merupakan suatu upaya rehabilitasi yang dapat diterapkan untuk mempercepat proses pemulihan suatu kawasan ekosistem terumbu karang yang rusak melalui penyediaan media penempelan (settlement) dan pertumbuhan karang[40].

Kegiatan rehabilitasi karang di Provinsi Bali dengan terumbu buatan dari berbagai jenis telah banyak dilakukan, salah satunya adalah menggunakan terumbu buatan alami "Bioreeftek" di perairan pesisir Desa Kerobokan, Kecamatan Sawan, Kabupaten Buleleng, Provinsi Bali. Perairan pesisir Desa Kerobokan. Penelitian ini fokus melakukan pendataan pada terumbu buatan alami dari tempurung kelapa "bioreeftek"[9]. Penelitian ini bertujuan untuk melihat nilai Indeks Keanekaragaman, Keseragaman dan Dominansi dari karang yang telah menempati dan tumbuh pada media bioreeftek di salah satu spot kawasan perairan desa Kerobokan, BaliUtara.

\section{METODE PENELITIAN}

\section{Waktu dan Tempat Penelitian}

Pengambilan data karang pada terumbu buatan alami Bioreeftek dilakukan dipesisir Desa Kerobokan, Kecamatan Sawan, Kabupaten Buleleng, Provinsi Bali (S 08004'53,6”; E $\left.115^{\circ} 07^{\prime} 08,8^{\prime \prime}\right)$ (Gambar 1) pada September 2020. Jumlah unit Bioreeftek yang di observasi terdiri dari enam unit dalam satu spot,yang telah di tenggelamkan sejak tahun 2014 pada kedalaman 5 meter pada substrat berpasir halus (Gambar 2B).

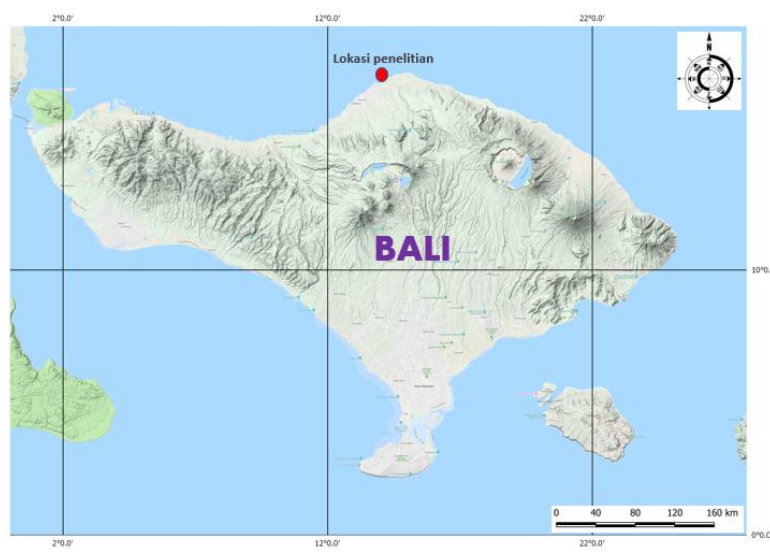

Gambar 1. Peta Lokasi Penelitian

\section{Prosedur pengambilan data}

Fotografi dan metode visual dengan time swim. Metode ini didefinisikan tidak merusak karena tidak memerlukan proses pengambilan sampel secara langsung oleh foto atau rekaman video, penghitungan dilakukan langsung di bawah air. Teknik sensus visual dibagi menjadi dua kategori utama: 1) survei sepanjang jalur yang telah ditentukan (transek); 2) pengambilan sampel titik secara spesifik dan terdefinisi dengan baik, serta menggunakan peralatan bernafas bawah air (SCUBA - Self Contained Underwater Breathing Apparatus)[15], [16]. Penelitian ini mengaplikasikan teknik sensus visual kategori 2. Pengambilan foto dan rekaman video dilakukan pada setiap sisi terumbu buatan yakni: atas, kanan, kiri atau menyesuaikan dengan posisi karang yang telah menempel pada terumbu buatan tersebut (Gambar2A).

\section{Identifikasi Karang}


Identifikasi karang dilakukan dengan melihat kenampakkan karang dari foto koloni, sehingga identifikasi karang baru dapat dilakukan setelah mendapatkan data berupa foto koloni karang pada spot rekrutmen berupa media

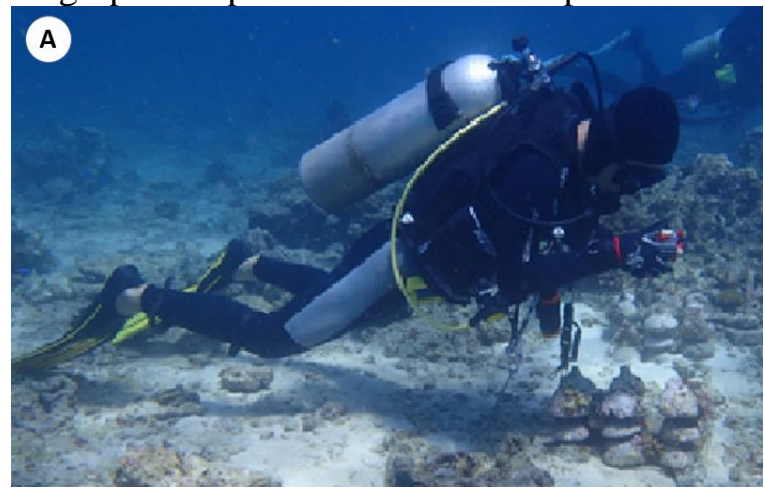

terumbu buatan "Bioreeftek" dilokasi penelitian. Bentuk koloni karang ditentukan dengan melihat foto koloni dan foto close up koralit lalu dibandingkan dengan buku identifikasi karang [17]

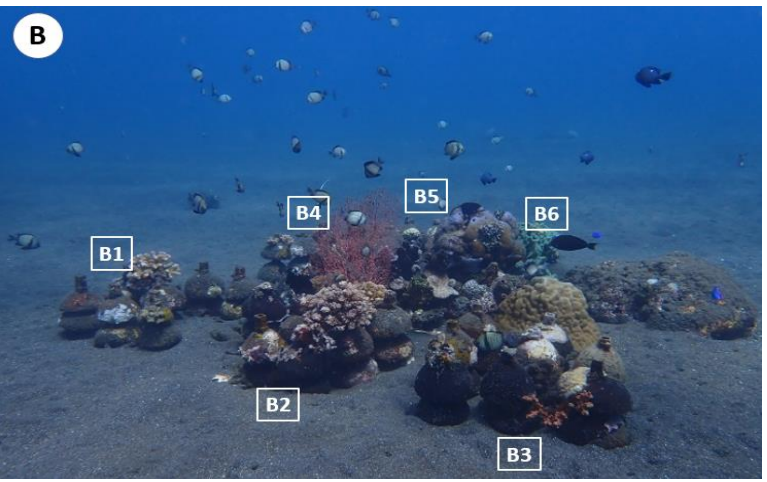

Gambar 2. A). Observasi dengan sensus visual menggunakan alat SCUBA dan kamera bawah air (Foto: D. Prasetia); B). 6 unit terumbu buatan dan asosiasinya pada salah satu spot di kawasan perairan desa Kerobokan (B1B6= jumlah unit terumbu buatan 'bioreeftek' yang di observasi)

\section{Analisis Data}

Identifikasi jenis biota pada terumbu buatan B1-B6 masing-masing dengan melihat jumlah dan jenis menggunakan nilai indeks:

- Indeks Keanekaragaman (H')

$$
H^{\prime}=-\sum_{i=1}^{n} p i \ln p i
$$

keterangan:

$\mathrm{H}^{\prime}=$ indeks keanekaragaman

$\mathrm{Pi}=$ ni / N

$\mathrm{Ni}=$ jumlah individu jenis ke- $\mathrm{i}$

$\mathrm{N}=$ jumlah total individu semua jenis

Kisaran indeks keanekaragaman [18]:

2,3026 = keanekargaman kecil dan kestabilan komunitas rendah

$2,3026<\mathrm{H}^{\prime}<6,9078=$ keanekaragaman sedang dan kestabilan komunitas sedang

$\mathrm{H}^{\prime}>6,9078=$ keanekaragaman tinggi dan kestabilan komunitas tinggi

- Indeks Keseragaman (E')

$$
E=\frac{H^{\prime}}{H_{\text {maks }}}
$$

Keterangan :

$\mathrm{E}=$ indeks keseragaman

Hmaks $=\ln \mathrm{S}$
$\mathrm{S}=$ jumlah spesies

Kisaran indeks keseragaman [19]:

$\mathrm{E}=0-1$;

E mendekati $0=$ sebaran individu antar jenis tidak merata/ada jenis tertentu yang dominan

E mendekati $1=$ sebaran individi antar jenis merata

- Indeks Dominansi (D)

Indeks Dominansi dihitung dengan menggunakan rumus indeks dominanasi dari Simpson [18]:

$\mathrm{D}=\sum(\mathrm{ni} / \mathrm{N}) 2$

Keterangan:

$\mathrm{D}=$ Indeks Dominansi Simpson

$\mathrm{Ni}=$ Jumlah individu tiap spesies

$\mathrm{N}=$ Jumlah individu seluruh spesies

Nilai indeks dominansi berkisar antara 0 sampai 1, dengan asumsi semakin kecil nilai Indeks Dominansi menunjukan tidak adanya dominansi atas suatu spesies tertentu. Sebaliknya, semakin besar nilai indeks menunjukan dominansi suatu spesies tertentu[20].

\section{HASIL DAN PEMBAHASAN}

Hasil observasi dan pendataan koloni karang pada spot rekruitmen terumbu buatan alami 
"Bioreeftek" di perairan pesisir Desa Kerobokan, Kecamatan Sawan, Kabupaten Buleleng ditemukan beberapa jenis biota. Biota yang paling tinggi jumlahnya adalah Coralline algae (Gambar 3). Keberadaan genus alga ini dapat menjadi indikasi perkembangan bioherm dan biostrome dan di beberapa perairan tropis dengan kondisi tertentu kehadiran koloni genus alga juga dapat mengindikasikan adanya kenaikan muka air laut (sea level rise) sekitar $10 \mathrm{~cm}$ [21].

\section{JENIS-JENIS BIOTA PADA TERUMBU BUATAN}

B1-B6

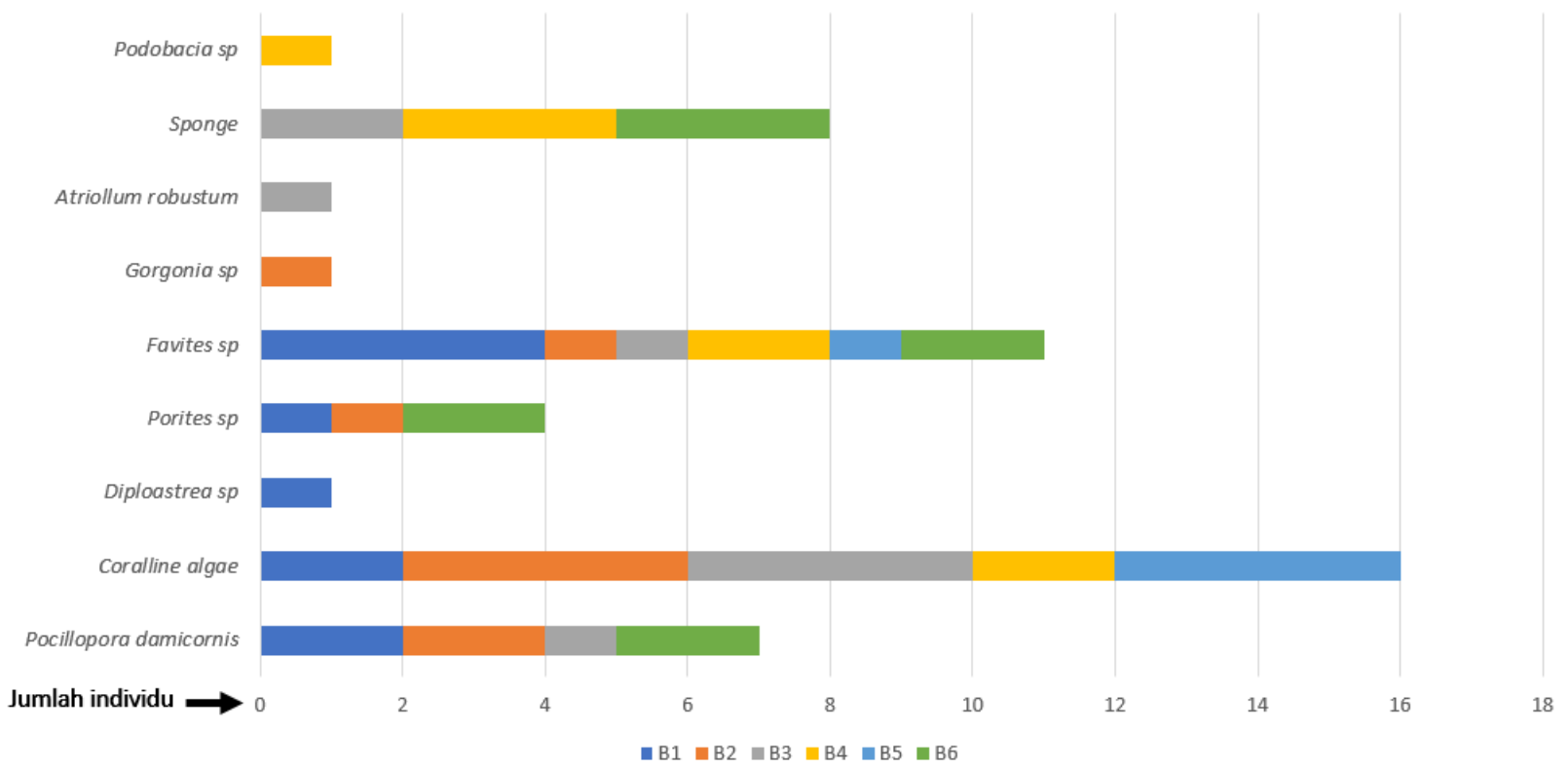

Gambar 3. Jenis-jenis biota hasil observasi yang tumbuh dan berkembang pada terumbu buatan bioreeftek

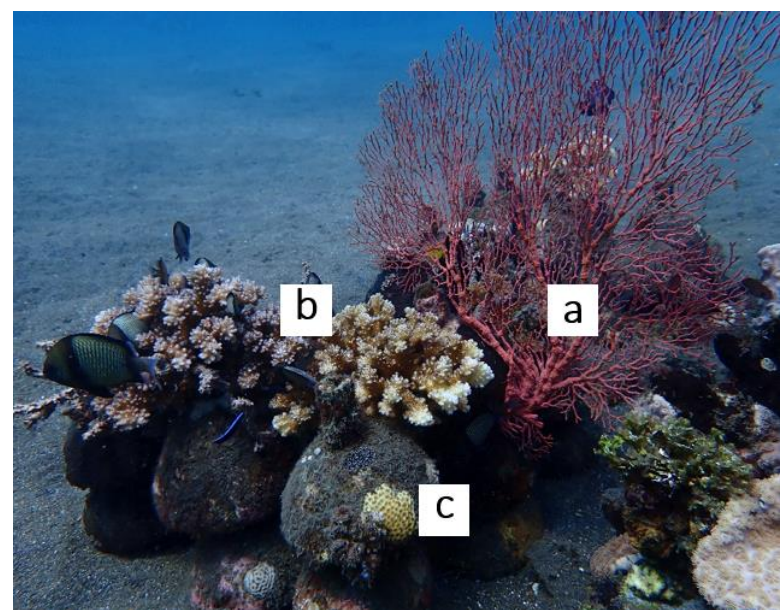

Gambar 4. Contoh foto hasil identifikasi biota a). Gorgonia sp, b). Pocillopora damicornis dan c). Favites $s p$ yang tumbuh (rekrutmen) secara alami pada bioreeftek (B2) yang berasosiasi dengan ikan karang
Hasil analisis indeks keanekaragaman menunjukkan kisaran nilai 0,50-3,44 dengan nilai rerata1,59 (Gambar 5a). Nilai indeks tersebut menunjukkan bahwa keanekaragaman di lokasitersebut termasuk dalam kategori kecil dan kestabilan komunitas rendah. Namun demikian, perhitungan nilai indeks keseragaman menunjukkan kisaran 0,31-2,48 dengan nilai rerata 1,08 (Gambar 5b). Nilai indeks tersebut menunjukan bahwa sebaran individu antar jenis di lokasi tersebut tergolong merata, yang berarti bahwa keseimbangan ekosistemnya cukup baik. Sejalan dengan tingginya indeks keseragaman, nilai dominansi yang diperoleh dari hasil analisis menunjukan kisaran 0,26-0,68 dengan nilai rerata 0,34 (Gambar 5c). Nilai indeks tersebut menunjukan bahwa di lokasi tersebut tidak ada spesies yang mendominansi. Ekosistem yang ideal dan stabil ditandai dengan nilai indeks 
keanekaragaman yang tinggi, keseragamannya mendekati nilai satu (tinggi), dan dominansinya mendekati nol (rendah). Rendahnya nilai indeks keanekaragaman di suatu ekosistem dapat dipengaruhi oleh tekanan lingkungan di sekitarnya, rendahnya tekanan lingkungan menyebabkan terumbu karang semakin produktif sehingga keanekaragaman terumbu karang dapat mencapai kondisi optimal [22].

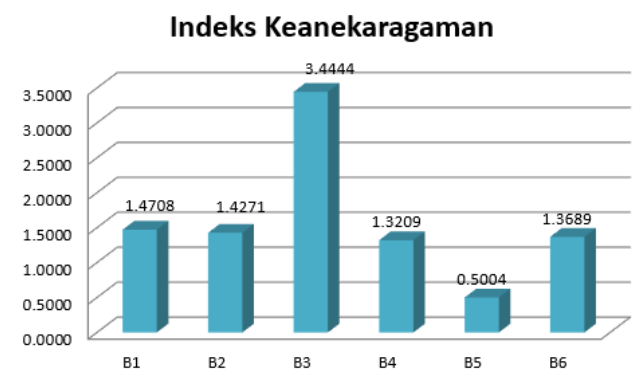

Indeks Keseragaman

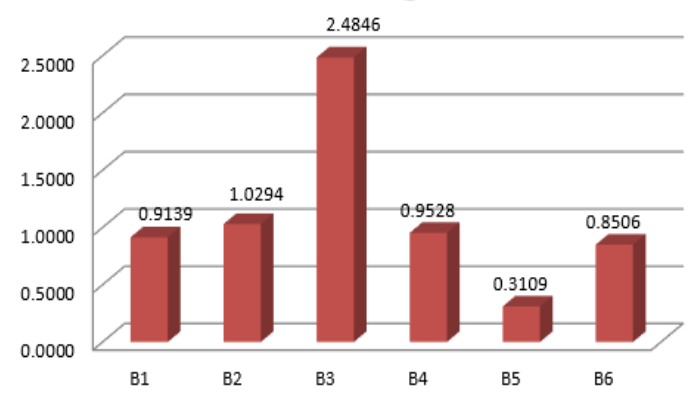

Indeks Dominansi

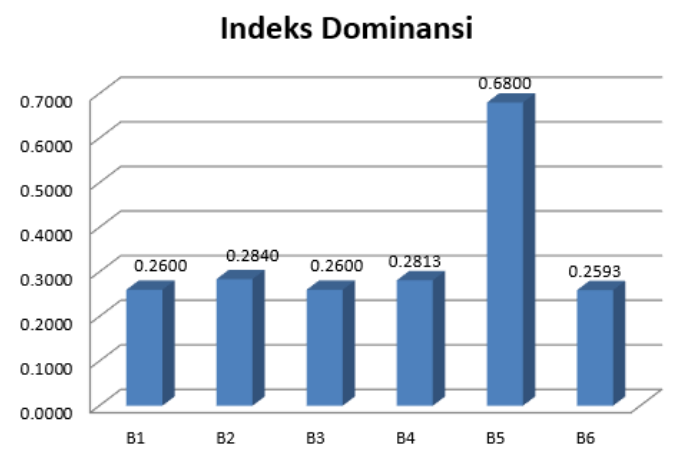

c.

Gambar 5. Nilai Indeks keanekaragaman (a), keseragaman (b), dan dominansi biota(c) pada terumbu buatan bioreeftek B1-B6

Hasil pengukuran parameter kualitas perairan yang dilakukan pada tahun 2014 - 2020 di Perairan Buleleng disajikan pada Tabel 1. Hasil analisis parameter fisika (suhu, turbiditas, kecepatan arus) dan kimia ( $\mathrm{pH}$, salinitas, nitrat, fosfat) menunjukkan bahwa perairan Buleleng dalam kondisi relatif baik dan stabil (tidak melebihi Baku Mutu Air Laut Untuk Biota Laut) [23], kecuali untuk parameter nutrien yang menunjukkan nilai rerata melebihi standar yang dipersyaratkan (namun tidak sampai mencapai nilai yang ekstrim).

Dari hasil pengukuran suhu perairan berkisar $27,07-30,96^{\circ} \mathrm{C}$ dengan rerata yaitu $29,19^{\circ} \mathrm{C}$. Suhu optimal bagi pertumbuhan karang berkisar $25-28^{\circ} \mathrm{C}$, dengan toleransi suhu pada kisaran $20^{\circ} \mathrm{C}$, sampai dengan $36-40^{\circ} \mathrm{C}$. Hasil pengukuran suhu masih berada dalam kisaran normal dan mendukung perkembangan rekrutmen karang. Fluktuasi suhu yang melebihi kisaran normal bagi kehidupan karang dapat berdampak pemutihan (bleaching) dan berlanjut pada kematian [30].

Nilai turbiditas yang terukur di Perairan Buleleng berkisar 0-24,75 NTU dengan nilai rerata 6,06 NTU. Turbiditas dapat mengurangi intensitas cahaya matahari yang masuk ke dalam perairan dan menyebabkan terganggunya proses fotosintesis zooxanthellae pada terumbu karang. Turbiditas dipengaruhi oleh proses sedimentasi yang berasal dari input daratan berupa aliran sungai yang bermuara ke laut. Turbiditas di perairan Buleleng masih dalam batas yang dapat ditoleransi oleh organisme karang, namun demikian terdapat potensi peningkatan turbiditas karena cukup dekat dengan daratan, sehingga merupakan ancaman bagi ekosistem terumbu karang [31].

Pengukuran kecepatan arus menunjukkan kisaran $0,20-0,80 \mathrm{~m} / \mathrm{dt}$ dengan rerata sebesar $0,42 \mathrm{~m} / \mathrm{dt}$. Arus penting untuk transportasi zat hara, larva, bahan sedimen dan oksigen yang dibutuhkan oleh karang. Arus dan sirkulasi air juga berperan dalam proses pembersihan dari endapan material yang menempel pada polip karang [32]. Kecepatan dan arah arus penting bagi populasi karang terutama pemencaran larva dan keberhasilan penempelan pada substrat [17], [33]. Selain itu, arus juga mempengaruhi bentuk terumbu karang [34]. 
Nilai pH yang terukur berkisar 7,20-8,45 dengan nilai rerata 7,86. Keberhasilan rekrutmen karang dipengaruhi oleh adanya interaksi antara larva karang dengan crustose coralline algae
(CCA). Hasil penelitian menunjukkan bahwa rendahnya $\mathrm{pH}$ dapat menurunkan laju dan proses rekrutmen karang, serta mengurangi kelimpahan CCA hingga $\geq 45 \%$ [35], [36].

Tabel 1. Nilai Parameter Kualitas Perairan

\begin{tabular}{|c|c|c|c|c|c|c|c|c|}
\hline Parameter Kualitas & 2014 & 2016 & 2017 & 2018 & 2019 & 2020 & Rerata & Baku Mutu \\
\hline Perairan [24] & [25] & [26] & [27] & [28] & [29] & Nilai & [23] & \\
\hline Suhu $\left({ }^{\circ} \mathrm{C}\right)$ & 28,33 & 30,96 & 27,07 & 29,56 & - & 30,04 & 29,19 & $28-30$ \\
\hline Turbiditas (NTU) & 0,71 & 3,34 & 7,24 & 0,31 & 0 & 24,75 & 6,06 & $<5$ \\
\hline Kecepatan arus $(\mathrm{m} / \mathrm{dt})$ & 0,20 & 0,25 & - & - & 0,80 & - & 0,42 & - \\
\hline $\mathrm{pH}$ & 7,60 & 7,20 & 7,78 & 8,21 & 8,45 & 7,90 & 7,86 & $7-8,5$ \\
\hline Salinitas (\%o) & 31,07 & 31,40 & 33,43 & 30,48 & 31,30 & 30,62 & 31,38 & $33-34$ \\
\hline Nitrat $(m g / L)$ & - & 0,41 & 0,06 & 0,01 & - & - & 0,16 & 0,008 \\
\hline Fosfat (mg/L) & - & 0,07 & 0,01 & 0,02 & - & - & 0,03 & 0,015 \\
\hline
\end{tabular}

Kisaran salinitas di Perairan Buleleng berkisar 30,48-33,43\%o dengan rerata 31,38\%o. Salinitas optimum bagi kehidupan karang berkisar antara 27-40\% [31]. Salinitas berpengaruh terhadap kematangan gonad dan keberhasilan penempelan larva pada substrat [37].[38] menyatakan bahwa salinitas berpengaruh pada rusaknya sel-sel penting yang berkembang secara fisiologis dari sistem perkembangan organisme karang.

Hasil pengukuran parameter nutrien (nitrat dan fosfat) menunjukkan nilai rerata melebihi standar Baku Mutu Air Laut untuk Biota Laut: Karang [23]. Untuk parameter nitrat didapatkan kisaran $0,01-0,41 \mathrm{mg} / \mathrm{L}$ dengan rerata sebesar 0,16mg/L (Baku Mutu: 0,008 mg/L). Sementara konsentrasi fosfat yang terukur menunjukkan kisaran $0,01-0,07 \mathrm{mg} / \mathrm{L}$ dengan rerata sebesar 0,03mg/L (Baku Mutu: 0,015 mg/L).Sumber kelebihan zat hara dapat berasal dari curah hujan yang tinggi dan input dari daratan yang dapat menganggu pertumbuhan terumbu karang melalui peningkatan sedimen dan terjadinya penurunan salinitas air laut. Kelebihan zat hara ini juga dapat berkontribusi terhadap degradasi terumbu karang melalui peningkatan pertumbuhan makroalga yang melimpah (overgrowth) terhadap karang [39].

\section{KESIMPULAN}

Terdapat sembilan tipe biota yang ditemukan pada spot rekrutmen karang di perairan Desa Kerobokan, Buleleng, Bali yaitu Podobacia sp, sponge, Atriollum robustum, Gorgonia, Favites, Porites, Diploastrea, Coralline algae dan Pocillopora domicornis. Biota yang paling banyak ditemukan adalah Coralline algae. Indeks Keanekaragaman dan Indeks Keseragaman tertinggi ditemukan di B3, berturut-turut dengan nilai 3,4 dan 2, 48; sementara Indeks Dominansi tertinggi ditemukan di B5, sebesar 0,68. Kondisi kualitas air di perairan Buleleng menunjukan kondisi normal dan masih dalam standar baku yang ditetapkan oleh Keputusan Menteri Lingkungan Hidup No. 51 Tahun 2004, kecuali konsentrasi nutrien.

\section{UCAPAN TERIMA KASIH}

Penelitian ini didanai dari dana DIPA Balai Riset dan Observasi Laut, Kementerian Kelautan dan Perikanan TA. 2020 kegiatan "Pemetaan Potensi Ikan, Pengawasan Sumberdaya, Kondisi Ekosistem Pesisir dan Validasi Laut Nusantara Menggunakan Data Satelit, Observasi dan Pemodelan"; sub kegiatan Kajian marine debris dan ekosistem pesisir. Penulis mengucapkan terima kasih kepada dosen dan mahasiswa FMIPA Program Studi D3 Budidaya Kelautan, 
Universitas Pendidikan Ganesha serta tenaga Penyuluh Perikanan dan Kelautan Kabupaten Buleleng yang telah membantu dalam survei, serta kepada semua pihak yang membantu kelancaran penelitian ini.

\section{DAFTAR PUSTAKA}

[1] J. E. N. Veron et al., "Delineating the Coral Triangle," Galaxea, Journal of Coral Reef Studies, vol. 11, hal. 91-100, Sep 2009.

[2] T. A. Hadi et al., "The Status of Indonesian Coral Reefs 2019," Research Center for Oceanography (RCO), COREMAP-CTI, Jakarta, Indonesia, 2020.

[3] C. K. Tito, E. E. Ampou, dan T. A. Wibawa, "Stressor-Response of Reef-Building Corals to Climate Change in the Menjangan Island, West Bali National Park, Indonesia," IOP Conf. Ser.: Earth Environ. Sci., vol. 246, 012011, May 2019, doi: 10.1088/17551315/246/1/012011.

[4] M. E. Lazuardi, I. K. Sudiarta, I. M. J. Ratha, E. E. Ampou, S. C. Nugroho, dan P. L. Mustika, "Chapter 4: The Status of Coral Reefs in Bali," in Bali Marine Rapid Assessment Program 2011, RAP Bulletin Biological Assessment of 64, Conservation International, Denpasar, Bali, Indonesia,hal. 69-77, 2012.

[5] E. Turak dan L. DeVantier, "Chapter 5: Biodiversity and Conservation Priorities of Reef-building Corals in Bali, Indonesia," in Bali Marine Rapid Assessment Program 2011, RAP Bulletin Biological Assessment of 64, Conservation International, Denpasar, Bali, Indonesia, hal. 78-130, 2012.

[6] A. Cruz-Trinidad, P. M. Aliño, R. C. Geronimo, dan R. B. Cabral, "Linking Food Security with Coral Reefs and Fisheries in the Coral Triangle," Coastal Management, vol. 42, no. 2, Art. no. 2, Mar. 2014, doi: 10.1080/08920753.2014.877761.

[7] E. Turak dan L. DeVantier, "Reef-building corals of Bunaken National Park, North Sulawesi, Indonesia: Rapid ecological assessment of biodiversity and status," Final Report to the International Ocean Institute
Regional Centre for Australia \& the Western Pacific, Sep 2003.

[8] E. E. Ampou, F. Sidik, C. Yusuf, N. D. Pertami, N. Widagti, dan A. Asri, "Marine Ecological Assessment in Bali and East Lombok Coast," presented at the World Ocean Conference, Manado, North Sulawesi, Indonesia, 2009.

[9] N. Widagti, E. E. Ampou, I. Triyulianti, dan Y. Pancawati, "Kajian Kawasan Konservasi Perairan di Nusa Penida, Bali," Prosiding Seminar Hasil Penelitian Terbaik Tahun 2010, Jakarta, Indonesia,hal. 212-223, 2010.

[10] T. J. Goreau, "Coral reef and Fisheries Habitat Restoration In The Coral Triangle: The Key To Sustainable Reef Management," Proceeding of Coral Reef Management Symposium on Coral Triangle Area, Jakarta, Indonesia, hal. 244-253, Okt 2009.

[11] E. E. Ampou et al., "Implementation of coral propagation for coral reef garden in Nusa Dua, Bali," IOP Conf. Ser.: Earth Environ. Sci., vol. 370, 012080, Dec. 2019, doi: 10.1088/1755-1315/370/1/012080.

[12] E. E. Ampou, G. I. Setiabudi, N. Widagti, dan I. D. I. Prasetia, "Coral diversity on artificial reef from coconut shells in northern Bali, Indonesia," Biodiversitas, vol. 21, no. 9, Art. no. 9, Agu 2020, doi: 10.13057/biodiv/d210952.

[13] A.L. Moulding,"Coral Recruitment Patterns in The Florida Keys,"J. Rev. de Biol. Trop., vol. 53, hal. 75-82, 2005.

[14] J. H. Connell, T. P. Hughes, dan C. C Wallace, "A 30-year study of coral abundance, recruitment, and disturbance at several scales in space and time,"J. Ecol. Mono., vol. 67, hal. 461-488, 1997.

[15] C. N. Bianchi et al., "Hard Bottoms," Biol. Mar. Medit., vol. 11, hal. 185-215, 2004.

[16] E. E. Ampou, "Caractérisation de la résilience des communautés benthiques récifales par analyse d'images à très haute résolution multi-sources: le cas du parc national de Bunaken, Indonésie," Université Toulouse III, Paul Sabatier, France, 2016.

[17] J. E. N. Veron,"Corals in Space and Time,"The Biogeography and Evolution of 
The Scleractinia, UNSW Press, Sidney, 1995.

[18] E. P. Odum, B. Srigandono, dan T. Samingan, Dasar-dasar ekologi, 3rd ed. Yogyakarta: Gadjah Mada University Press, 1993.

[19] C. E. Shannon dan W. Weaver, "The Mathematical Theory of Communication," 10th ed. USA: The University of Illinois Press, Urbana, 1964.

[20] T. J. Pitcher, A. E. Magurran, dan I. J. Winfield, "Fish in larger shoals find food faster," Behav Ecol Sociobiol, vol. 10, no. 2, hal. 149-151, Apr. 1982, doi: 10.1007/BF00300175.

[21] W. H. Adey, "Coralline algae as indicators of sea-level,"Sea Level Research, hal. 229280, 1986.

[22] A. Mutahari, I. Riyantini, L.P.S. Yuliadi, dan W. Pamungkas, "Analisis Kondisi Terumbu KarangisEp Kawasan Pariwisata dan Non Pariwisatastepidi Perairan Gugus Pulau Kelapa Kecamatan Kepulauan Seribu Utara,"Jurnal Perikanan dan Kelautan,vol. X,no. 2, hal. 43-49, Des2019.

[23] Keputusan Menteri Negara Lingkungan Hidup Nomor 51 Rahun 2004 Tentang Baku Mutu Air Laut

[24] Balai Penelitian dan Observasi Laut, "Survey Batimetri dan Pengamatan Kondisi Kualitas Air di Perairan Musi, Gerokgak, Bali untuk Budidaya Laut," Laporan Kegiatan Survei, hal. 1-37 hal., Sep 2014.

[25] S. A. Alif, I. W. G. A. Karang, dan Y. Suteja, "Analisis Hubungan Kondisi Perairan dengan Terumbu Karang di Desa Pemuteran Buleleng Bali," Journal of Marine and Aquatic Sciences, vol. 3, no. 2, hal. 142-153, Mei 2017.

[26] Balai Riset dan Observasi Laut, "Sistem Informasi Spasial untuk Daerah Penangkapan Ikan dan Perubahan Lingkungan Pada Ekosistem Pesisir," Laporan Kegiatan Riset, hal. 1-49, Des 2017.

[27] Balai Riset dan Observasi Laut, "Observasi Kondisi Terumbu Buatan (Bioreeftek) dan Sebaran Mikroplastik pada Ekosistem
Pesisir di Provinsi Bali Buleleng," Laporan Kegiatan Riset, hal. 1-65, Des 2018.

[28] E. C. Sinaga, I. W. Restu, dan R. Ekawaty, "Kajian Kualitas Air, Potensi Karang dan Ikan Karang untuk Pengembangan Wisata Selam di Desa Bondalem, Buleleng, Bali," Current Trends in Aquatic Science, vol. III, no. 1, hal. 39-46, Feb 2020.

[29] Balai Riset dan Observasi Laut, "Pemetaan Potensi lkan, Pengawasan Sumberdaya, Kondisi Ekosistem Pesisir dan Validasi Laut Nusantara Menggunakan Data Satelit, Observasi dan Pemodelan, Laporan Kegiatan Riset, hal. 1-49, Des 2020.

[30] Suharsono, "Bleaching event followed by mass mortality of corals in 1998 in Indonesian waters," dalam: Romimohtarto (ed) Proceeding the Ninth Joint Seminar on Marine and Fisheries Sciences, Bali, 7-9 Desember 1998, Jakarta: JSPS-LIPI, hal. 179-187, Des 1999.

[31] Supriharyono, "Pengelolaan Ekosistem Terumbu Karang," Djambatan, Jakarta, hal. 1-129, 2007.

[32] Giyanto, M. Abrar, T. A. Hadi, A. Budiyanto, M. Hafizt, A. Salatalohy, dan M. Y. Iswari, "Status Terumbu Karang Indonesia 2017," COREMAP-CTI Pusat Penelitian Oseanografi, Jakarta, hal 1-30, 2017.

[33] R. H. Richmond, "Reproduction and recruitment in corals: Critical links in the persistence of reef," dalam: Birkeland (ed). Life and death of coral reefs, Chapman \& Hall, New York, hal. 175-197, 1997.

[34] Supriharyono, "Pelestarian dan Pengelolaan Sumber Daya Alam di Wilayah Pesisir Tropis," Pustaka Pelajar, Yogyakarta, Indonesia, hal. 1-246, 2000.

[35] C. Doropoulos, S. Ward, G. Diaz-Pulido, O. Hoegh-Guldberg, dan P. J. Mumby, "Ocean Acidification Reduces Coral Recruitment by Disrupting Intimate Larval-Algal Settlement Interactions," Ecology Letters, vol. 15, no. 4, hal. 338-346, Apr2012.

[36] N. S. Webster, S. Uthicke, E.S. Botte, F. Flores dan A.P. Negri, "Ocean Acidification Reduces Induction of Coral Settlement by Crustose Coralline Algae,"Global Change 
Biology, vol. 19, no. 1, hal. 303-315, Jan 2013.

[37] C. Bierkeland, "Life and Death of Coral Reefs," Chapman and Hall, New York, hal. 1-536, 1997.

[38] N. P. Zamani, dan T. Arifin, "Hubungan Parameter Lingkungan terhadap Gangguan Kesehatan Karang di Pulau Tunda Banten," Jurnal Kelautan Nasional, vol. 11, no. 2, pp. 105-118, 2016.

[39] L. J. McCook, "Macroalgae, Nutrients and Phase Shift on Coral Reef: Scientific Issue and Management Consequences for the Great Barrier Reef," Coral Reef, vol. 18, hal. 357-367, Des 1999.

[40] A. Andayani and E. E. Ampou, "Pemanfaatan Bioreeftek Sebagai Alternatif Terumbu Buatan di Kabupaten Buleleng, Bali," in Rehabilitasi Ekosistem Terumbu Karang Untuk Keberlanjutan Sumberdaya Perikanan, 1st ed., Jakarta, Indonesia: Amafrad Press - Badan Riset dan Sumberdaya Manusia Kelautan dan Perikanan, 2018, pp. 111-128. 